Running head: Construction of British national identity

\title{
The construction of British national identity among British South Asians
}

\author{
Rusi Jaspal, Ph.D.* \\ School of Sociology and Social Policy, University of Nottingham \\ Marco Cinnirella, Ph.D. \\ Department of Psychology, Royal Holloway, University of London
}

This paper explores the socio-psychological aspects of British national identification among British South Asians, which constitutes the largest ethnic minority group in Britain. Identity Process Theory can elucidate the social and psychological 'functions' of Britishness for social actors, offering a holistic account of national identification within this population. The paper provides a discussion of nationhood and the construction of national identity, temporal factors in national identification, its cognitive and affective aspects, the psychological 'functionality' of Britishness, and its social representations. It is argued that a civic, instrumental conception of Britishness might facilitate access to this identity among British South Asians.

Keywords: national identity; nation; identity process theory; social representations; South Asians; social psychology; sociology

* Correspondence: Dr Rusi Jaspal, Institute for Science and Society, School of Sociology and Social Policy, Law and Social Sciences Building, University of Nottingham, Nottingham NG7 2RD, United Kingdom. E-mail: rusi.jaspal@gmail.com

\section{AUTHOR BIOGRAPHIES}

Dr Rusi Jaspal is a Social Psychologist and Research Fellow in the School of Sociology and Social Policy at the University of Nottingham. He has a long-standing interest in the interrelations between social representation, identity and social action. Rusi Jaspal is author of Anti-Semitism and Anti-Zionism: Representation, Cognition and Everyday Talk (Ashgate, 2013) and co-editor (with Glynis M. Breakwell) of Identity Process Theory: Identity, Social Action and Social Change (Cambridge University Press, 2012).

Dr Marco Cinnirella obtained his PhD in Social Psychology from the London School of Economics. He is currently a Senior Lecturer in Social Psychology at Royal Holloway, University of London, where his research focuses on applied aspects of intergroup relations and social identity.

\section{ACKNOWLEDGEMENTS}

This research was supported by a Thomas Holloway grant awarded to the first author. 


\title{
The Construction of British National Identity among British South Asians
}

\author{
Rusi Jaspal, Ph.D. \\ School of Sociology and Social Policy, University of Nottingham \\ Marco Cinnirella, Ph.D. \\ Department of Psychology, Royal Holloway, University of London
}

This paper explores the socio-psychological aspects of British national identification among British South Asians, which constitutes the largest ethnic minority group in Britain. Identity Process Theory can elucidate the social and psychological 'functions' of Britishness for social actors, offering a holistic account of national identification within this population. The paper provides a discussion of nationhood and the construction of national identity, temporal factors in national identification, its cognitive and affective aspects, the psychological 'functionality' of Britishness, and its social representations. It is argued that a civic, instrumental conception of Britishness might facilitate access to this identity among British South Asians.

Keywords: national identity; nation; identity process theory; social representations; South Asians; social psychology; sociology

British national identity is a complex and sometimes highly contentious social psychological issue. Contemporary discussions of Britishness tend to examine how it can now be defined in an era of ethnic 'super-diversity' and what 'Britishness' actually means to Britain's ethnic minorities (Vertovec, 2007). Accordingly, there has been much media, political and public debate concerning Britishness among ethnic minorities (Parekh, 2000). These discussions frequently anchor the issue of Britishness to national loyalty and implicitly or explicitly highlight some form of necessary rivalry between British national and ethnic/ religious identities (Jaspal \& Cinnirella, 2010b). Contradictions between these identities are often 
emphasised, while commonalities and points of connection are rarely acknowledged (cf. Bradley, 2008). In some cases, this has created a dilemmatic sense of identity among British South Asians (BSA), Britain's largest ethnic minority group, given that individuals may feel excluded from the national group or made to choose between their national and ethnic/ religious identities (Ghuman, 2003).

Understandably, British national identity among ethnic minority individuals has attracted considerable scholarly attention, particularly from sociologists and anthropologists (Karner, 2011; Kumar, 2003; Smith, 1991). Recently there has been research into national identity among BSA which has taken a social psychological stance (Cinnirella \& Hamilton, 2007; Jaspal, 2011a; Vadher \& Barrett, 2009). It is surprising that, despite public and media debates around Britishness, the loyalty of BSA and the 'compatibility' of their national, ethnic and, more recently, religious identities (Modood et al. 1997; Saeed, 2007), social psychologists have not systematically examined the socio-psychological processes and mechanisms associated with the construction of British national identity and its management alongside other identities. It is argued that a contextualised examination of the sociopsychological 'functions' performed by Britishness among BSA is necessary in order to understand national identification among this demographically important population. Drawing upon tenets of Identity Process Theory (Breakwell, 1986), this paper explores the qualitative nature of Britishness among BSA and its potential social psychological antecedents.

\section{British South Asians: An Overview}

The term 'British South Asian' (BSA) constitutes a superordinate ethno-racial category, used typically to refer to individuals of Indian, Pakistani or Bangladeshi descent. In addition to this superordinate category, individuals may employ more specific ethnic categories, such as 
'Indian', 'Pakistani' or 'Bangladeshi' (Jacobson, 1997b; Saeed, Blaines \& Forbes, 1999), and even narrower ethno-regional categories (e.g. Panjabi or Gujarati) for self-definition, particularly in sociolinguistic contexts (Jaspal \& Coyle, 2010). In short, various ethnic identificatory possibilities are available to BSA (Jaspal, 2011b).

National identification among BSA can be complex, since social representations of national identity are multifarious, rendering the perceived criteria for national ingroup membership unclear. To better understand these representations, it is necessary to examine briefly the historical sociology of BSA. The socialisation of first-generation BSA in largely collectivist societies in India and Pakistan, which prioritise the notion of kinship ('biraderi' and 'izzat'), coupled with their commitment to the 'myth of return' (to India/ Pakistan), rendered their sense of national identity largely unproblematic in the early phase of settlement (Bolognani, 2007). They simply did not lay claim to a British national identity and saw themselves first and foremost as Indians or Pakistanis (Ballard, 1994). In fact, norms and values perceived to be associated with Britishness (e.g. drinking alcohol, going to nightclubs, having casual premarital sex) were in fact highly stigmatised by South Asian immigrants (Ballard, 1994). This could have rendered Britishness even less appealing.

However, most BSA migrants did not return to their countries of origin but settled in industrial areas with thriving textile industries such as Yorkshire and the Midlands, as well as in West London (Peach, 2006). Today BSA of Indian, Pakistani and Bangladeshi descent constitute approximately half of the ethnic minority population in the UK (Scott, Pearce \& Goldblatt, 2001), the majority of whom were born and raised in Britain. Furthermore, many first-generation BSA have spent most of their lives in the UK. These shifts in demographic and socio-economic factors have facilitated social and psychological changes, precipitated by increased contact between BSA and the White British majority (WBM) in the domains of employment, housing and other spheres of social life. Moreover, the mixed schooling of the 
second-generation alongside the WBM and the development of stronger social ties between BSA and the WBM have highlighted the need to think critically about what Britishness means to BSA and how accessible the national construct actually is to them. The vicissitudes of first-hand experience of living in Britain and the inter-relations of ethnic and national identities have certainly shaped the way that people view and relate psychologically to Britishness. Britain is no longer viewed solely as the economic haven it represented during the early phases of settlement (Hiro, 1973), but rather as 'home' to most BSA and especially to the second-generation who tend to view the Subcontinent primarily as a holiday destination (Harris, 2006). Accordingly, this paper explores the construction of British national identity among BSA.

\section{Identity Process Theory}

Some of the major debates on national identity include issues around its contribution to one's sense of self. Identity Process Theory (IPT) (Breakwell, 1986, 2001; Jaspal and Cinnirella, 2010a; Vignoles, Chryssochoou \& Breakwell, 2002) is proposed as a suitable theoretical framework for understanding the motivational aspects of national identification. IPT proposes that the structure of self-identity should be conceptualised in terms of its content and value/affect dimensions and that this structure is regulated by two universal processes, namely the assimilation-accommodation process and the evaluation process. The assimilation-accommodation process refers to the absorption of new information in the identity structure (e.g. 'I am British') and the adjustment which takes place in order for it to become part of the structure (e.g. 'I am British, hence I won't support a foreign football team'). The evaluation process confers meaning and value on the contents of identity (e.g. 'Being British is a good thing'). 
Breakwell (1986, 2001) has identified four identity principles which are said to guide these universal processes, namely: continuity across time and situation (continuity); uniqueness or distinctiveness from others (distinctiveness); feeling confident and in control of one's life (self-efficacy); and feelings of personal worth (self-esteem). Extending IPT, Vignoles, Chryssochoou and Breakwell (2002) have proposed two additional identity 'motives', namely belonging, which refers to the need to maintain feelings of closeness to and acceptance by other people, and meaning, which refers to the need to find significance and purpose in one's life. More recently, Jaspal and Cinnirella (2010a) have proposed the psychological coherence principle, which refers to the motivation to establish feelings of compatibility between their (interconnected) identities. IPT acknowledges the importance of social representations in shaping how social phenomena will impact the identity principles. According to IPT, a 'social representation is essentially a construction of reality' (Breakwell, 1986, p. 55), which determine the social and psychological meanings attached to surrounding social stimuli (Moscovici, 1988).

IPT suggests that if the universal processes cannot comply with the motivational principles of identity, for whatever reason, identity is threatened and the individual will engage in strategies for coping with the threat. A coping strategy is defined as 'any activity, in thought or deed, which has as its goal the removal or modification of a threat to identity' (Breakwell, 1986, p. 78). For instance, a British Pakistani woman may experience threats to the psychological coherence principle if she feels that the norms and values associated with her British national and Pakistani ethnic identities, respectively, are incompatible and contradictory (Jaspal \& Cinnirella, 2010a). In order to cope with the threat, she may choose to accentuate her identification with her ethnic group and, conversely, to distance herself from her British national identity. Vignoles, Chryssochoou \& Breakwell (2002) provide empirical support for the hypothesis that those identities (e.g. national, ethnic, religious) that 
best satisfy the identity principles will be perceived as most central to one's self-concept. Thus, the more a given identity is perceived by the individual as a source of self-esteem, selfefficacy, distinctiveness, meaning, continuity, belonging and psychological coherence, the more central it will be to the self-concept.

An underlying premise of the theory is that, in order to understand the processes that guide identity construction, it is necessary to examine how individuals react when identity is threatened. Recent research suggests that BSA may be susceptible to identity threat within the context of British national identification (Jaspal, 2011a). Firstly, as noted above, BSA might experience difficulties in reconciling their ethnic and national identities, given the differing norms, values and social representations associated with these identities (Ghuman, 2003), potentially threatening psychological coherence. Secondly, BSA may feel excluded from the national group by the WBM because the practices, norms and values associated with their ethnic identities may be widely perceived to be incompatible with Britishness (Hopkins, 2004; Jacobson, 1997a; Vadher and Barrett, 2009), with negative outcomes for the belonging principle. Thirdly, there is some empirical evidence that BSA, and particularly British Pakistanis, are socially represented in primarily negative terms (Phillips, 2006), which can impede a positive self-conception among BSA, thereby threatening the self-esteem principle. These examples highlight the potential suitability of applying IPT to the issue of British national identification among BSA.

\section{The Nation and National Identity}

In his historical account of the development and reception of nationalism, Anderson (1983, p. 6) defined the nation in terms of 'an imagined political community that is imagined as both inherently limited and sovereign'. It is imagined since members will never know all of their fellow-members 'yet in the minds of each lives the images of their communion' (p. 7). Thus, 
the individual categorises him-/herself as a member of the national group (Turner et al., 1987), despite not being personally acquainted with the majority of their co-nationals. This group membership can provide feelings of acceptance and inclusion, which in turn facilitates a sense of belonging (Baumeister \& Leary, 1995). However, there is empirical evidence that many BSA do not in fact 'imagine' the national community as united and inclusive of their ethnic ingroup, which can constitute a phenomenologically important group membership (Modood et al., 1997). This may be attributed to perceived discrimination from the WBM on the grounds of ethnicity and religion (Vadher \& Barrett, 2009). This potential inability to imagine one's ethnic or religious ingroup as a 'legitimate' subgroup within the national ‘community' can in turn call into question one's self-inclusion as an individual (Turner et al., 1987), potentially decreasing the ability of British national identity to serve the belonging principle.

Subsequent to Anderson's (1983) ground-breaking work on (national) communities, scholars have attempted to elucidate the various conceptual dimensions of the nation. Smith (1991, p. 14) defines the nation as 'a named human population sharing a historic territory, common myths and historical memories, a mass, public culture, a common economy and common legal rights and duties for all members'. While these are implicitly presented as 'objective' features of a nation, from a socio-psychological perspective it is necessary to examine social representations regarding geographic territory, common myth and common duties among BSA, since these are important in shaping one's sense of national identity (Cinnirella, 1996, 1997b). For instance, Lord Tebbit's 'Cricket Test' for ethnic minority groups served to construct support for Britain's cricket team as a national 'duty' (Fletcher, in press). While this may seem a reasonable assertion among the WBM, many BSA seem to express support for the cricket teams associated with their ethnic groups, which need not necessarily reflect a weak sense of Britishness (Williams, 2000). The central point is that 
social representations regarding 'common duties' are not uniform and coercive (or hegemonic) across British society, but are fluid, complex and specific to particular subgroups within the national collective (see Cinnirella \& Hamilton, 2007).

In terms of the sources of these representations, Guibernau (2007, p. 21) observes that education and the media are two important institutions that enable individuals to 'imagine' their nations as 'territorially bound, distinct and sovereign'. They constitute key sources of social representations (Cinnirella, 1996). However, it is reasonable to assume that BSA and the WBM may have differing levels and types of exposure to education and the media and that they may in fact respond to the same representations differently (Breakwell, 2001). For instance, in a rhetorical psychology study of the British monarchy, Billig (1992) observed that the (primarily White) British public consensually constructed the monarchy as a key tenet of Britishness, which could be attributed to the temporal and spatial hegemony of this social representation in British society. Conversely, Jaspal (2011a) has observed less consensus regarding the centrality of the British monarchy in the discourse of his BSA participants. When social representations of British colonialism (in India) acquired salience in the interview context, participants appeared to construct the British monarchy in negative terms as an unnecessary, archaic aspect of Britishness. It is noteworthy that individuals, as members of particular social groups, will personalise social representations partly in accordance with the interests of their immediate ingroups (Breakwell, 1993). Thus, it is necessary to examine the group interests, aims and goals of BSA in specific contexts in order to make hypotheses regarding their responses' to particular social representations of the nation.

Guibernau (2007) highlights that both invented and real attributes sustain a belief in the sense of common ancestry which habitually forms the basis of national identity, although it is acknowledged that there are other conceptions of nationhood which do not prioritise 
common ancestry (see Smith, 1991). These national attributes can be considered 'real' in a psychological sense, since individuals themselves perceive these as reflecting 'reality'. Moreover, they are perceived as inherent and immutable, rather than imagined. Like the 'imagination' of the nation itself, the perception that one possesses the 'crucial' attributes of national group membership is likely to enhance the belonging principle, which motivates individuals to perceive feelings of inclusion within the national group and acceptance from other national group members (Baumeister \& Leary, 1995). Moreover, given that these attributes are usually longstanding and grounded in a historical 'narrative' of the nation, the act of laying claim to these national attributes may enhance a sense of continuity between past, present and future (Triandafyllidou, 2001). Nonetheless, there may be a discrepancy between the longstanding national attributes historically associated with Britishness and those which BSA perceive themselves to possess (Jaspal, 2011a), which can potentially inhibit a sense of belonging in the national group.

In addition to this sense of common ancestry, Guibernau (2007) suggests that the values, beliefs, customs, habits and conventions and languages perceived to be associated with the nation constitute the 'cultural' dimension of national identity. However, the delineation of psychological and cultural dimensions of national identity in this way is misleading from a socio-psychological perspective, since it implicitly essentialises these values, beliefs, customs, conventions and languages and overlooks the fact that these phenomena themselves are themselves perceived by social actors (Reicher \& Hopkins, 2001). They are perceived through particular interpretive lenses (e.g. group memberships and personality traits) (Breakwell, 2001). Moreover, these social representations can be strategically personalised in order to achieve particular social and psychological functions. For instance, while binge-drinking may be regarded as a key 'custom' of Britishness by British Pakistanis when the aim is to highlight one's disidentification with the nation 
(Hopkins, 2004), the 'custom' may be completely downplayed or ignored by the very same individuals when the aim is, conversely, to affirm one's membership in the national group (Jaspal, 2011a). This highlights the 'constructedness' of social representations of national tenets and the agency that individuals have in constructing national identity (Breakwell, 1986).

As Connor (1994, p. 43) remarks, 'it is the self view of one's group rather than the tangible characteristics that is of essence in determining the existence or non-existence' of a national identity. Thus, what Guibernau (2007) refers to as the 'cultural' dimension of national identity is best described in terms of the content dimension of national identity, which, both socially and psychologically, 'comprises the defining properties of the identity, the characteristics which the individual concerned considers actually to describe himself or herself' as a national ingroup member (Breakwell, 1986, p. 12). These are psychological in that they are perceived and can be strategically embraced or rejected by groups and individuals in accordance with broader psychological processes. When the belonging principle acquires psychological salience, that is, when the psychological need is to construct oneself as a group member, it is likely that one will affirm one's possession of 'key' selfaspects perceived to be associated with Britishness (Jaspal \& Coyle, 2010). Conversely, when, for instance, distinctiveness is salient, that is, when it is personally/ socially valued to derive a sense of difference, it is possible that the individual will resist these elements of the nation.

Groups and individuals collectively develop representations of the values, beliefs and customs which comprise the content dimension of national identity (Moscovici, 1988). However, it is noteworthy that social representations of Britishness among BSA are not necessarily the same as those held and encouraged by the WBM. For instance, Ballard (1994, p. 13) notes that many first-generation BSA 'saw their White neighbours' lifestyles, their 
standards (or lack of them) of personal hygiene, the apparent absence of any sense of personal dignity, and the individualism and hedonism of their everyday lives' as unacceptable, suggested that 'British' values were viewed as being inferior. Furthermore, Jaspal and Cinnirella (2010a) have demonstrated that even second-generation British Pakistanis can sometimes perceive what they view as British norms and values particularly within the domain of sexuality to be 'excessively' liberal. While hegemonic social representations of what it means to be British will be shared across a whole society, polemic representations are associated with particular subgroups (e.g. BSA) (Moscovici, 1988). Thus, research into national identity, which aims to encompass the diverse perspectives, interests, aims and goals of both majority and minority group members, must accommodate the rich tapestry of social representations, both hegemonic and polemic, which are held and encouraged by the multiple groups and subgroups within a society (Breakwell, 1993). Their development over time is an important issue.

\section{Temporal Factors in National Identity Construction}

Temporal factors play an important role in the construction of national identity. There is no universal consensus regarding how far one should look back in order to ascertain the roots of a nation (Guibernau, 2007; Smith, 1989). For instance, is the Turkish presence in Cyprus sufficiently longstanding in order for Turkish Cypriots to be considered a 'nation'? Does the 2000-year Jewish claim to the Land of Israel make competing national claims from other groups to the very same land indefensible? Indeed, 'history contributes to the construction of a certain image of the nation and represents the cradle where the national character was forged' (Guibernau, 2007, p. 20). Therefore, it is necessary to explore social representations of history in constructing, managing and even defending one's national identity (Hilton \& Lio, 2008). It has been found that individuals can 'substantiate' their claims to membership in 
ethnic groups by highlighting the membership among 'a long lineage of individuals bound together by a common heritage' (Jaspal \& Cinnirella, in press, p. 9). The perception of 'common ancestry' can similarly be central to one's national identity. Given that this is not possible for many BSA, individuals may feel compelled to doubt their own 'authenticity' as a national group member. However, there is evidence that the 'criteria' for ingroup-outgroup boundaries can be strategically reconstructed in order to facilitate a sense of belonging in desired social groups (Jaspal \& Coyle, 2010). An important question concerns how BSA respond to social representations regarding temporality as a criterion for 'authentic' national membership.

At a more micro level, a key concern regarding temporality in national identity among first-generation BSA relates to their early experiences upon arrival and settlement in Britain. Much research highlights perceptions and first-hand experiences of racism and discrimination among the early migrants to Britain (Jacobson, 1997b; Jaspal, 2011a). It has been noted that social representations of South Asian migrants to Britain were generally negative among the WBM (Brah, 1996). They were viewed as an alien and undesirable presence in Britain, which should be isolated rather than integrated into society. This perception seemed to be further reiterated in immigration legislation, which became increasingly stricter in the early stages of settlement, as well as the lack of anti-racism legislation protecting BSA from discrimination (Solomos, 1993). Qualitative research with first-generation BSA has exhibited their acute awareness of these stigmatising social representations and a consequential lack of belonging within the nation (Jaspal, 2011a). It is noteworthy that these perceptions and experiences could plausibly shape one's sense of national attachment among first-generation BSA, since they may constitute the primary basis or source of social representations regarding the acceptance and inclusion of BSA in the national group and WBM attitudes towards the ethnic ingroup. This demonstrates the importance of developing a temporally sensitive narrative of 
national identity among BSA, which examines the potential links between experiences of discrimination and national identification. While it is possible that BSA draw upon early social representations in the construction of British national identity, those BSA individuals who anchor Britishness primarily to their instrumental achievements in Britain and to subsequent egalitarian and prosperous stages of settlement in Britain might be expected to exhibit an instrumental attachment to Britishness, regardless of these early experiences (Kelman, 1969).

Similarly, 'generational temporality' may be an important factor in the construction of national identity. There is, for instance, a need to explore the inter-generational transmission of accounts of Britishness, since it is possible that experiences of racism and discrimination reported by first-generation BSA may well shape the sense of national attachment among the second-generation (Jacobson, 1997b). The perception that the WBM have historically discriminated against the first-generation may threaten the sense of belonging in the national group among the second-generation, given that this may be regarded as 'otherisation' of the ethnic group as a whole. Furthermore, the perception that co-members of one's ethnic ingroup have been subjected to derogation and denigration may inhibit a positive selfconception, resulting in decreased self-esteem (Gecas, 1982).

Social representations of historical relations between Britishness and the ethnic 'homeland' can similarly shape British national identity among BSA (Jaspal \& Cinnirella, in press). The anchoring of Britishness to colonialism and the subjugation of the Indian Subcontinent may, similarly, inhibit national attachment among this group (Cinnirella \& Hamilton, 2007). This may be attributed to the potentially negative outcomes for the continuity principle, since one's desired or actual self-identification with Britishness could be disrupted by exposure to the social representation that that Britain subjugated the Indian Subcontinent. This would be particularly applicable to those individuals whose ethnic 
attachment is strong. Conversely, those BSA who temporally delineate or compartmentalise colonial Britishness from a contemporary, inclusive and egalitarian Britishness might be expected to embrace Britishness more readily (see also Bradley, 2008). This compartmentalisation of the imperial past and inclusive, egalitarian present essentially redefines what it means to be British and may allow BSA access to this national identity. Moreover, the social representation that Britain exploited the Indian Subcontinent articulated by some BSA could induce disidentification with the national group, given the potential threats to the psychological coherence principle (in relation to British national and Indian ethnic identities) (Jaspal, 2011a). Individuals may feel that it is impossible to identify with a national group that 'abused' their ethnic ingroup.

Further research should examine how BSA subjectively remember, feel and talk about national and ethnic histories, such as relations between Britishness and the ethnic 'homeland' and early experiences of discrimination among BSA, in order to assess the perceived availability of a British national identity and to understand how indeed individuals construct their national identities (Smith, 1989). This would allow insight into the 'historical' social representations of Britishness which are salient to individuals (Breakwell, 2001; Cinnirella, 1996), the emotions which are evoked in relation to these representations and how the representations are employed in talk in order to justify one's (dis-)identification with Britishness. The next section examines the cognitive and affect aspects of national identification.

\section{Cognitive and Affective Aspects of National Identity}

Social psychologists are typically concerned with the cognitive and affective aspects of national identification (Barrett, 2000; David \& Bar-Tal, 2009). Barrett (2000) has outlined various cognitive aspects of national identification, which include (i) knowledge of the 
existence of the national group; (ii) self-categorisation as a member of the national group; (iii) knowledge of the national geographical territory; (iv) knowledge of national emblems; and (v) beliefs about common descent and kinship among group members. Given this focus on belief and knowledge, which are derived at least partly from social representations disseminated in channels of societal information, insights from social representations theory are of particular heuristic value (Moscovici, 1988).

It has been hypothesised that individuals will personalise social representations in accordance with the principled operation of identity processes, that is, in ways which provide individuals with feelings of self-esteem, continuity, distinctiveness and so on (Breakwell, 1993, 2001). Group memberships often determine the extent to which specific social representations facilitate these desirable end-states for identity. For instance, one's membership in the Pakistani (ethnic) group could render the social representation that Pakistanis are disloyal to Britishness threatening for the psychological coherence principle (in relation to national and ethnic identities). Individuals may be motivated either to resist this social representation or to choose between their conflicting group memberships (Breakwell, 1986; Jaspal \& Cinnirella, 2010a). Accordingly, the personalisation of social representations of the nation may vary in accordance with ethnic background. BSA are likely to personalise social representations of the nation (i.e. knowledge of the national group) in ways, which facilitate these desirable end-states for identity. For instance, while some members of the WBM may regard Britain's imperial past in terms of national pride and thereby derive feelings of self-esteem from this national past (Economist poll, cited in Wellings, 2008, p. 405), BSA might plausibly evaluate Britain's imperial past negatively, due to its perceived negative consequences for India, the ethnic homeland (Cinnirella \& Hamilton, 2007). Indeed, the social representation that India was subjugated by British colonialism could induce perceptions of weak self-efficacy of the Indian ethnic ingroup during colonial times - 
weakened self-efficacy is of course not a desirable end-state for identity (La Guardia et al., 2000). In short, knowledge of the nation, that is, of its existence, territory and emblems, is likely to be personalised by BSA in ways that enhance identity. It is necessary to examine how BSA invoke and personalise social representations of the existence, territory and emblems of Britishness, in order to further understand these cognitive aspects of Britishness.

In addition to the cognitive aspects of national identity, Barrett (2000, p. 8) describes its affective aspects, that is, 'the feelings, emotions and evaluations which make up the sense of national identity'. Affective aspects of national identity include, inter alia, (i) the subjective importance that one attaches to their national identity; (ii) one's evaluation of it; (iii) one's sense of attachment to the identity; (iv) the emotional attachment to the national geographical territory; and (v) social emotions such as national guilt, embarrassment or pride and feelings towards the national ingroup and outgroups. The evaluation process of identity (as outlined in IPT) performs these affective functions of national identity. The evaluation process entails 'the allocation of meaning and value to [national] identity content both new and old' (Breakwell, 1986, p. 23). In attributing value to identity elements, one determines their importance and attachment to them, which in turn generates particular emotional reactions to them. Crucially, the evaluation process of identity will function in tandem with the assimilation-accommodation process of identity, which determines the content of identity (Breakwell, 1986). Therefore, social representations of Britishness and the ethnic ingroup which populate the self-concept will to a large extent determine the meanings and values attached to national identity. Moreover, there is a need to examine Britishness within the broader context of the self, which consists of other, potentially competing identities (e.g. religious, ethnic). This is particularly important among BSA individuals, some of whom may regard their religious identity (Jacobson, 1997b) or ethnic identity (Hutnik, 1991) as 'core' 
vis-à-vis Britishness. In short, the affective aspects of national identity among BSA can only be understood when considered within the broader context of the self.

Previous research among British Pakistanis suggests that national identity is less of a priority vis-à-vis ethnic and religious identities, which may conversely be more central to the self-concept (Jacobson, 1997b). This sense of disidentification with Britishness could be attributed to the observation that many British Pakistanis do not feel a sense of belonging in the national group which itself is partly a consequence of the perceived lack of acceptance and inclusion from the WBM (Vadher \& Barrett, 2009). Indeed, experiences of racism and discrimination may induce threats to the belonging principle, which can in turn motivate individuals to derive feelings of acceptance and inclusion from alternative group memberships (while disidentifying from the national group membership) (Breakwell, 1986; Jaspal, 2011a). In addition to their gradual disidentification with the national group, 'otherised' individuals may begin to attribute negative valence to the (threatening) national group and, hence, to the construct of Britishness in general.

Moreover, it is expected that the evaluation process would function to create negative intergroup relations with the stigmatising national group (e.g. the WBM). For instance, Jaspal and Coyle (2010) highlight that SGSA can interpret intercultural behaviour (e.g. 'language crossing' which refers to an outgroup's use/ appropriation of vocabulary or other language forms that are usually associated with the ingroup) of WBM members in terms of ridicule, racism or 'trespassing' on ingroup 'territory'. This may be attributed to suspicion of the intentions and activities of the outgroup, which are regarded within the broader context of perceived racism and discrimination (Moy \& $\mathrm{Ng}$, 1996). Initial exclusion from the category Britishness can lead to disidentification with the national category, its negative evaluation and ultimately negative intergroup relations. The negative valence attributed to Britishness (and, by extension, to remaining members of this category) can mean that alternative group 
memberships at the same level of abstraction (e.g. national and religious groups) become more 'core'. Individuals come to derive feelings of belonging from the alternative group memberships and it is likely that, subsequent to disidentification with Britishness, individuals will seek to derive appropriate levels of the other identity principles from these alternative group memberships. For instance, if Britishness as a primary source of self-efficacy ceases to provide BSA individuals feelings of control and competence due, for instance, to discrimination in the workplace, it is conceivable that individuals will turn to their ethnic group for feelings of self-efficacy. More specifically, BSA may feel that they can produce desired effects to improve their ethnic group's social standing in society through collective action (e.g. participation in pressure groups) as ethnic group members (Bandura, 2000).

\section{Identity Functionality of Britishness}

IPT theorists argue that social categories acquire psychological salience or 'centrality' insofar as they serve the principled operation of identity processes (Vignoles, Chryssochoou \& Breakwell, 2000, 2002). This highlights the importance of investigating how national identity might affect identity processes. Kelman (1997) states that, insofar as a group of individuals come to regard themselves as constituting 'a unique identifiable entity' (distinctiveness), 'with a claim to continuity over time' (continuity), 'to unity across geographical distance' (belonging) and 'to the right of various forms of self-expression' (self-efficacy), one can say that they have developed a sense of national identity. Kelman's (1997) work seems to suggest that the principles of distinctiveness, continuity, belonging and self-efficacy must be served by national identification.

Accordingly, it is possible to talk of the psychological functionality of national identification. However, the identity functionality of Britishness for BSA may well differ from that of the WBM. For instance, the WBM may well derive feelings of continuity from 
their British national identity if they perceive the identity as reflecting their membership among 'a long lineage of individuals bound together by a common heritage', that is, in ethnic terms (Jaspal \& Cinnirella, in press, p. 9). On the other hand, it has been suggested that among BSA the continuity principle may be more pertinently associated with ethnic rather than British national identity (Jaspal \& Cinnirella, in press). Indeed, the self-efficacy principle has been found to constitute a statistically significant predictor of British national identification among BSA (Jaspal, 2011a), which may be attributed to the generally instrumental, materialistic nature of British national attachment among BSA (Vadher \& Barrett, 2009).

This suggests that in order to understand the identity functionality of Britishness among BSA it is necessary to examine the qualitative nature of national attachment. In his typology of national attachment, Kelman (1969, p. 279) highlights two specific types of 'ties between individual members and the system [nation]'; national attachment can be either sentimental or instrumental. Instrumental attachment to the nation is considered to be a rational one, since it involves the individual's assessment of the subjective, instrumental benefits of belonging to the nation. Individuals who hold an instrumental attachment to the nation regard the nation as helping to realise materialistic goals, e.g. by providing access to education, wealth etc. Conversely, sentimental attachment to the nation is largely emotional and requires close correspondence between national values and the personal values of the individual. It is closely related to tradition, cultural achievement of the nation and one's dedication to national symbols. Crucially, BSA tend to perceive their attachment to Britishness in instrumental terms, that is, as a source of their materialistic goals (Vadher \& Barrett, 2009).

Vadher and Barrett (2009) observe an instrumental attachment to Britishness among their second-generation BSA participants. Similarly, one of the primary motives for mass 
migration of BSA to Britain was the anticipated economic benefits of migration, which suggests that instrumental national attachment is a logical outcome (Ballard, 1994; Hiro, 1973). Instrumental group attachment is likely to be associated with the self-efficacy and selfesteem principles of identity, since a primary function of the identity is to provide feelings of control and competence and a positive self-conception from the acquisition of material benefits (e.g. education, employment, wealth). Conversely, sentimental group attachment is likely to be associated with the belonging, continuity and meaning principles, given the emotional and existential nature of this form of attachment (Kelman, 1969). Research suggests that BSA tend to manifest an instrumental attachment to Britishness and a more sentimental attachment to their ethnic identity (Jaspal \& Cinnirella, in press; Vadher \& Barrett, 2009). Accordingly, (civic) national and ethnic identities may curb each other's limitations by collectively enhancing distinct identity principles, that is, both identities may perform distinct but complementary, mutually beneficiary functions for the self-concept.

\section{Conceptions of Britishness}

Scholars have examined the qualitative nature of Britishness, that is, what it means to be British in contemporary Britain (e.g. Bradley, 2008; Parekh, 2000). Kiely, McCrone \& Bechhofer (2005) highlight the various different conceptions of Britishness in both England and Scotland, as well as among Scottish-born migrants in England and English-born migrants in Scotland. They argue that Britishness may be viewed as (i) a synonym for 'Englishness'; (ii) symbolising the possession of a British passport; (iii) a symbol of a regrettable, primarily racist past; (iv) a proud and nostalgic legacy of 'greatness'; (v) a statement of political unity between the nations, which could be positive or negative; (vi) 'a liberal, civic identity uniting peoples of diverse nations and ethnicities under a common umbrella of statehood' (p. 79). The authors demonstrate the diverse meanings attached to Britishness in a sample of White 
Britons. Britishness can evoke civic, ethnic or racial connotations, which may be evaluated positively or negatively in accordance with context (see also Modood et al., 1997). In order to understand how BSA respond to these social representations and how they construct their own representations of Britishness, it is necessary to explore both the qualitative nature of their national attachment and how particular social representations of Britishness might affect identity processes. For instance, those BSA who manifest a civic, instrumental attachment to Britishness would be unlikely to regard the category as synonymous with 'Englishness', while those who feel excluded from the national group and therefore manifest no national attachment might well share this view. Indeed, endorsement of the social representation that Britishness is a synonym for 'Englishness' might perform an attributional function in that it may be employed to explain 'why' one cannot identify with Britishness (Hewstone \& Augoustinos, 1998).

Furthermore, the competing social representations concerning Britishness as a symbol of a regrettable, racist past, on the one hand, and as a proud and nostalgic legacy of 'greatness', on the other, are also observable in interview research with BSA (Jaspal, 2011a). It has been found that BSA may articulate both social representations (in the same interview) in accordance with context; when the aim is to present oneself as a national group member (despite competing claims that South Asians are 'less' British), BSA may lay claim to national nostalgia. Conversely, when the aim is to distance oneself from Britishness, due for instance to its perceived incompatibility with a 'core' custom of one's ethnic identity, BSA can further reiterate their disidentification with Britishness by reproducing the social representation that it symbolises a regrettable, racist past. Identity processes may explain the apparently contradictory ways of personalising social representations (Breakwell, 2001). In particular contexts it may become socially and culturally 'valued' to express a sense of belonging in the national group, particularly when one's position within the national group is 
being questioned, as is observable in the case of Muslims post-9/11 (Field, 2007). The social desirability of asserting one's belonging in the national group may encourage individuals to express a nostalgic social representation of Britishness. Conversely, when the social context prioritises affiliation to the ethnic group (vis-à-vis the national group), the psychological coherence principle may acquire psychological salience, encouraging BSA to lay claim to the competing representations and thereby safeguard a sense of coherence.

\section{Boundaries of Britishness}

There has been much debate regarding the (im-)mutability of national identity. Indeed, Poole (1999, p. 12) argues that 'we come to feel that our national identity is as natural and inescapable as our gender', suggesting that the identity is fairly resistant to change over time, that is, static and immutable.

In attempting to explain these social representations of nationhood, sociologists of national identity have differentiated between the two distinct 'models' of nationhood, namely the 'ethnic' and the 'civic' models. An 'ethnic' conceptualisation of the nation posits that common ancestry and biological ancestry are fundamental prerequisites for inclusion within the national group. Britishness is largely understood to be primordial in that individuals are regarded as being 'born' into the group. However, proponents of the ethnic conception of nationhood are usually opposed to the notion that one 'becomes' British as a result of being born in British territory. Indeed, members of the far-right British National Party have observed that 'just because a dog is born in a stable doesn't make it a horse' (Hundal, 2010). Rather, it is suggested that one can only be British 'by blood'. Conversely, a 'civic' conception of Britishness refers to a voluntary association of individuals who share common legal and political rights and duties (Smith, 1991). According to this model, the acquisition of British citizenship provides eligibility for self-inclusion in the national group. It is 'relatively 
open or inclusive in the sense that it delineates a conception of Britishness which encompasses the large majority of members of ethnic minorities in Britain' (Smith, 1991, p. 189).

The ethnic social representation of Britishness is unlikely to facilitate a sense of belonging within the national group among BSA, largely because individuals cannot usually lay claim to British 'background'. Often, debates regarding Britishness among ethnic minorities acquire salience in the media and other channels of societal information subsequent to specific social triggers (e.g. the involvement of ethnic minority individuals in a terrorist plot). As Cinnirella (1997a) has noted, 'dormant' social representations of Britishness regarding can suddenly become active in the public sphere. It has been observed that, following the July $7^{\text {th }}$ bombings in London, some BSA individuals noted radical changes in the ways in which they were viewed and treated by the WBM, which led several individuals to feel that they were no longer 'accepted' in the national group (Jaspal, 2011a). The notion of change is crucial here; when individuals' self-representation as British is somehow obstructed by a change in the social context (i.e. the activation of a dormant ethnic social representation of Britishness), this may plausibly be threatening for the continuity principle (Breakwell, 1986). Conversely, the social representation of civic Britishness could be expected to facilitate a sense of belonging in the national group, while safeguarding continuity of self-definition as a national group member. Moreover, this representation of nationhood is likely to have favourable outcomes for the psychological coherence principle, since the civic model of Britishness, in principle, enables BSA to lay claim to both (British) national and (Indian/ Pakistani) ethnic identities. More specifically, one's Indian/ Pakistani ethnic identity can continue to be perceived in ethnic terms, while one's British national identity is construed as a civic, citizenship-based national identity. 
In an article exploring the nature of British national attachment among British Pakistani youth, Jacobson (1997a) draws upon the civic and ethnic divide in order to develop her model of the 'boundaries of Britishness'. These boundaries define the contents of Britishness and the permeability of ingroup and outgroup boundaries. It is appropriate to conceptualise these boundaries in terms of social representations, since a social representation refers to a system of ideas, values and practices in relation to a given social object. Elaborating Smith's (1991) dichotomy of national identity, Jacobson (1997a) argues that these boundaries can be 'racial', 'cultural' or 'civic'. In addition to the civic and ethnic/ racial conceptions of Britishness, Jacobson (1997a) describes the 'cultural' boundary of Britishness. This refers to the expectation that one will engage in behaviour, life-styles and adopt values, which are perceived to be shared among national ingroup members. This might be more adequately conceptualised in terms of the expectation that one will accept, internalise and reproduce hegemonic cultural representations regarding what it means to be British.

BSA may find it difficult to endorse norms and values perceived to be associated with Britishness, since these may be regarded as contradicting those associated with their ethnic group memberships. This may include conflicting norms regarding sexuality and family life (Ballard, 1994; Jaspal \& Cinnirella, 2010a) and the perceived normativity of binge-drinking in British culture (Hopkins, 2004; Vadher \& Barrett, 2009), for instance. The cultural boundary of Britishness may induce threats to the psychological coherence principle by highlighting tensions between the norms and values perceived to be associated with one's national and ethnic identities, respectively. Accordingly, it is necessary to explore the interrelations between norms and values perceived to be associated with Britishness and ethnic identity, as well as the willingness of individuals to adopt norms and values of Britishness. The investigation of these two factors would determine the extent to which feelings of 
acceptance and inclusion can be derived from Britishness among BSA who accept the cultural boundary of Britishness.

In their elaboration of Jacobson's (1997a) model, Vadher and Barrett (2009) outline additional boundaries of Britishness, including the instrumental, historical and multicultural boundaries. The instrumental boundary is differentiated from the civic boundary in that it entails the evaluation of Britishness 'along the dimensions of meeting the legal, political, career and/ or educations needs and interests of the respondent' (Vadher \& Barrett, 2009, p. 451). To that extent, it owes a certain debt to the Kelman's (1969) instrumental-sentimental dichotomy of national identity. It could be hypothesised that employing the instrumental boundary of Britishness would have favourable outcomes for the self-efficacy principle, given its provision of feelings of control and competence through achievement and material gain. Research suggests that many BSA do in fact accept the instrumental boundary of Britishness (Jaspal, 2011a).

The historical boundary refers to the importance of self-inclusion within the historical or mythological 'story' of the nation in order to acquire membership in the national group. Indeed, BSA may indeed feel excluded from Britishness due to the perceived injustices of the British Empire (Cinnirella \& Hamilton, 2007), as well as the narratives of racism offered by first-generation BSA in the early stages of settlement in Britain (Jaspal, 2011a). The historical boundary of Britishness can be better understood by exploring the temporal factors of British national identification, as highlighted above. This in turn would eludicate the impact of accepting the historical boundary of Britishness for identity processes.

The multicultural boundary of Britishness 'allows all to be included within the [national] category, while allowing the maintenance of one's own values and beliefs, especially within the home' (Vadher \& Barrett, 2009, p. 452). Adherence to this boundary is likely to provide feelings of acceptance and inclusion within this "national community- 
without-commonality' (Condor, 2006, p. 668), thereby enhancing the belonging principle. Although some psychological theories of social identity highlight an inherent tension between establishing feelings of belonging and distinctiveness (e.g. Brewer, 1991), it seems that the multicultural boundary would, in principle, facilitate feelings of distinctiveness as well as belonging, given that individuals are also able to maintain their own ethno-cultural values and beliefs, which differentiate them from outgroups. However, it is noteworthy that the multicultural boundary of Britishness has become highly contested in social and media discourses in contemporary Britishness, particularly given that prominent politicians have declared multiculturalism a 'failure' (see Modood, 2007). In an era of suspicion and doubt regarding the Britishness of ethnic minorities, BSA may be motivated to accept hegemonic social representations perceived to be associated with Britishness, as a means of safeguarding feelings of national belonging and self-esteem (Jaspal, 2011a). Thus, it is unclear whether BSA will continue to accept the multicultural boundary of Britishness.

These boundaries implicitly define the contents of Britishness, the criteria for membership in the national group, and the kind of practices which are deemed necessary in order to be an 'authentic' member of the national group. Moreover, they seem to have distinct

outcomes for identity processes. More generally, it is necessary to explore how these boundaries are constructed and how they shift in accordance with social context, particularly in the aftermath of key societal events, in order to understand the construction of British national identity.

\section{Conclusions}

This paper provides an overview of key issues concerning the construction of British national identity among BSA. The vast social sciences literature on national identity has addressed a multitude of areas, such as the cognitive and affective, social, temporal and historical 
dimensions of national identity. Yet, these interrelated dimensions have rarely been examined collectively. It is argued that insights from IPT can make an important contribution to bridging these disparate areas, thereby enhancing our understanding of national identification among BSA. Furthermore, the theory can demonstrate some of the ways in which BSA will respond to and personalise social representations of the nation, that is, the 'cultural' dimension of the nation (Guibernau, 2007). One of the key contributions of the theory is its recognition of self-agency in constructing identity and human resourcefulness in protecting it from threat.

Dominant theories of national identity provide important insight into the 'objective' aspects of nationhood, such as the existence of national myths and territorial boundaries, as well as the processes underlying the formation of national groups, such as the establishment of national unity across geographical distance. Conversely, this paper critically examines these universal aspects and processes specifically within the context of Britishness among BSA. While much existing theory and research concerning national identity tends to focus upon the dominant group, this paper provides particular insight into how and why ethnic minority groups such as BSA may lay claim to a British national identity (see also Cinnirella \& Hamilton, 2007). Crucially, it is argued that a universalistic approach to national identity is unlikely to be effective in elucidating the construction of national identity among specific ethnic minority groups, since the ways in which individuals personalise social representations of the nation (e.g. national duties) may be unique to their specific social contexts, goals and group interests. Furthermore, this paper posits that the study of national identity construction must be sensitive to temporal factors, rather than synchronic and static. Thus, it is necessary to examine how BSA subjectively remember, feel and talk about national and ethnic histories, such as relations between Britishness and the ethnic 'homeland' and early experiences of discrimination among BSA, in order to understand national identity construction. 
The motivational principles of belonging, distinctiveness, continuity and self-efficacy seem to be most pertinently associated with national identity construction. It is necessary to examine the nature of national attachment among BSA in order to understand how national identification may impinge upon the principled operation of identity processes. On the basis of previous work which suggests that BSA tend to manifest an instrumental, rather than sentimental, attachment to Britishness, it appears that the continuity principle may be less relevant to British national identity. Rather, their instrumental attachment to Britishness may mean that the self-efficacy principle is more relevant. Furthermore, there is empirical evidence that BSA may fail to derive feelings of acceptance, inclusion and belonging from Britishness due to perceived discrimination from the WBM. On a related note, it is argued that national identity construction among BSA must be examined within the broader context of the self, which encompasses potentially competing identities at the same level of abstraction, such as ethnic and religious identities. This highlights the potential salience of the psychological coherence principle in relation to the interconnected national and ethnic/ religious identities. More generally, it is argued that the construction of Britishness among BSA must be contextualised satisfactorily in order to understand which principles of identity acquire salience in particular social contexts. The principles acquire psychological salience insofar as they become culturally valued in a given context (Breakwell, 1986).

The discussion presented in this paper suggests that the encouragement of a civic conception of Britishness may help to facilitate an instrumental attachment to the national group among BSA. This may in turn enable Britishness to better serve identity processes and to facilitate a sense of coherence between their (instrumental) national and (sentimental) ethnic identities, which can sometimes seem incompatible and contradictory. This is likely to to facilitate the assimilation-accommodation of Britishness in the self-concept and the positive evaluation of this identity. Scholars, policy-makers and the media must facilitate 
these processes and thereby facilitate a British national identity among those who desire it, both majority and minority group members alike.

\section{REFERENCES}

Anderson, B. (1983). Imagined Communities. London: Verso.

Ballard, R. (1994). Introduction: the emergence of Desh Pardesh. In R. Ballard (Ed.), Desh

Pardesh: The South Asian Experience in Britain (pp. 1-35). London: C. Hurst \& Co.

Bandura, A. (2000). Exercise of human agency through collective agency. Current Directions in Psychological Science, 9(3), 75-78.

Barrett, M. (2000). The development of national identity in childhood and adolescence.

Inaugural lecture presented at the University of Surrey, 22nd March 2000.

Baumeister, R. F. \& Leary, M. R. (1995). The need to belong: desire for interpersonal attachments as a fundamental human motivation. Psychological Bulletin, 117, 497-529. Billig, M. (1992). Talking of the Royal Family. London: Routledge

Bolognani, M. (2007). The myth of return: Dismissal, survival or revival? A Bradford example of transnationalism as a political instrument. Journal of Ethnic and Migration Studies, 33(1), 59-76.

Bradley, I. (2008). Believing in Britain: The Spiritual Identity in Britishness. Oxford: Lion Hudson Plc.

Brah, A. (1996). Cartographies of Diaspora: Contesting Identities. London: Routledge.

Breakwell, G.M. (1986) Coping with Threatened Identities. London: Methuen.

Breakwell, G.M. (1993). Social representations and social identity. Papers on Social

Representations, 2(3), 1-20.

Breakwell, G.M. (2001). Social representational constraints upon identity processes. In K.

Deaux \& G. Philogène (eds.), Representations of the Social: Bridging Theoretical Traditions (pp. 271-284). Oxford: Blackwell.

Brewer, M.B. (1991). The social self: on being the same and different at the same time.

Personality and Social Psychology Bulletin, 17, 475-482.

Cinnirella, M. (1996). A social identity perspective on European Integration. In G. M.

Breakwell \& E. Lyons (Eds.), Changing European Identities: Social Psychological Analyses of Social Change (pp. 253-273). Oxford: Butterworth-Heinemann.

Cinnirella (1997a). Ethnic and national stereotypes: a social identity perspective. In C.C. Barfoot (Ed.), Beyond Pug's Tour: National and Ethnic Stereotyping in Theory and Literary Practice (pp. 253-274). Amsterdam: Editions Rodopi

Cinnirella, M. (1997b). Towards a European Identity? Interactions between the national and European social identities manifested by university students in Britain and Italy. British Journal of Social Psychology, 36, 19-31.

Cinnirella, M. \& Hamilton, S. (2007). Are all Britons reluctant Europeans? Exploring European identity and attitudes to Europe among citizens of South Asian ethnicity. Ethnic and Racial Studies, 30(3), 481-501.

Condor, S. (2006). Temporality and collectivity: Diversity, history and the rhetorical construction of national entitativity. British Journal of Social Psychology, 45, 657-82.

Connor, W. (1994). Ethnonationalism: The Quest for Understanding. Princeton, New Jersey: Princeton University Press

David, O. \& Bar-Tal, D. (2009). A sociopsychological conception of collective identity: The case of national identity as an example. Personal and Social Psychology Review, 13(4), 35479 . 
Field, C.D. (2007). Islamophobia in contemporary Britain: the evidence of the opinion polls, 1988-2006. Islam and Christian-Muslim Relations, 18, 447-77.

Fletcher, T. (in press). "Who do 'they' cheer for?" Cricket, diaspora, hybridity and divided loyalties amongst British Asians. International Review for the Sociology of Sport.

Gecas, V. (1982). The self-concept. Annual Review of Sociology, 8, 1-33.

Ghuman, P.A.S. (2003). Double Loyalties: South Asian Adolescents in the West. Cardiff:

University of Wales Press.

Guibernau, M. (2007). The Identity of Nations. Cambridge: Polity Press.

Harris, R. (2006). New Ethnicities and Language Use. Basingstoke: Palgrave Macmillan.

Hewstone, M., \& Augoustinos, M. (1998). Social attributions and social representations. In

U. Flick (Ed.), The psychology of the Social (pp.60-76). Cambridge: Cambridge University Press.

Hiro, D. (1973). Black British, White British. Harmondsworth: Penguin.

Hopkins, P. E. (2004). Young Muslim men in Scotland: inclusions and exclusions. Children's Geographies, 2(2), 257-272.

Hundal, S. (2010). From now on I'm English, not British. The Guardian, 23 June 2010.

Available at http://www.guardian.co.uk/commentisfree/2010/jun/23/english-british-nationalidentity-ethnic-minorities

Hutnik, N. (1991). Ethnic Minority Identity: A Social Psychological Perspective. New York: Oxford University Press.

Jacobson, J. (1997a). Perceptions of Britishness. Nations and Nationalism, 3(2), 181-199.

Jacobson, J. (1997b). Religion and ethnicity: dual and alternative sources of identity among young British Pakistanis. Ethnic and Racial Studies, 20(2), 238-256.

Jaspal, R. (2011a). The construction and management of national and ethnic identities among

British South Asians: an identity process theory approach. Ph.D. dissertation, Royal

Holloway, University of London, UK.

Jaspal, R. (2011b). Delineating ethnic and religious identities in research with British South

Asians. Psychological Studies, 56(2), 214-244

Jaspal, R. \& Cinnirella, M. (in press). The construction of ethnic identity: insights from identity process theory. Ethnicities.

Jaspal, R. \& Cinnirella, M. (2010a). Coping with potentially incompatible identities: accounts of religious, ethnic and sexual identities from British Pakistani men who identify as Muslim and gay. British Journal of Social Psychology, 49(4), 849-870.

Jaspal, R. \& Cinnirella, M. (2010b). Media representations of British Muslims and hybridised threats to identity. Contemporary Islam: Dynamics of Muslim Life, 4(3), 289-310.

Jaspal, R. \& Coyle, A. (2010). "My language, my people": language and ethnic identity among British-born South Asians. South Asian Diaspora, 2(2), 201-218.

Karner, C. (2011). Negotiating National Identities: Between Globalisation, the Past and 'the Other'. Farnham: Ashgate.

Kelman, H.C. (1969). Patterns of personal involvement in the national system: a socialpsychological analysis of political legitimacy. In J.N. Rosenau (Ed.), International Politics and Foreign Policy: A Reader in Research and Theory (pp. 276-88). New York: Free Press. Kelman, H.C. (1997). Nationalism, patriotism and national identity: social psychological dimensions. In D. Bar-Tal \& E. Staub (Eds.), Patriotism in the Lives of Individuals and Nations (pp. 165-189). Chicago: Nelson-Hall.

Kiely, R. McCrone, D. \& Bechhofer, F. (2005). Whither Britishness? English and Scottish people in Scotland. Nations and Nationalism, 11(1), 65-83.

Kumar, K. (2003). The Making of English National Identity. Cambridge: Cambridge University Press. 
La Guardia, J. G., Ryan, R. M., Couchman, C. E. \& Deci, E. L. (2000). Within-person variation in security of attachment: A self-determination theory perspective on attachment, need fulfillment and well-being. Journal of Personality and Social Psychology, 79, 367-384. Modood, T. (2007). Multiculturalism. A Civic Idea. Cambridge: Polity Press. Modood, T., Berthoud, R., Lakey, J., Nazroo, J., Smith, P., Virdee, S. \& Beishon, S. (1997). Ethnic Minorities in Britain: Diversity and Disadvantage. London: Policy Studies Institute.

Moscovici, S. (1988). Notes towards a description of social representations. European Journal of Social Psychology, 18, 211-50.

Moy, J. \& Ng, S.H. (1996). Expectation of outgroup behaviour: can you trust the outgroup? European Journal of Social Psychology, 26(2), 333-40.

Parekh, B. (2000). Defining British national identity. The Political Quarterly, 71(1), 4-14.

Peach, C. (2006). South Asian migration and settlement in Great Britain, 1951-2001.

Contemporary South Asia, 15(2), 133-46.

Phillips, D. (2006). Parallel lives? Challenging discourses of British Muslim self-segregation. Environment and Planning D: Society and Space, 24, 25-40.

Poole, R. (1999). The Nation and Identity. London: Routledge.

Reicher, S. \& Hopkins, N. (2001) Self and Nation. London: Sage.

Saeed, A. (2007). Media, racism and Islamophobia: the representation of Islam and Muslims in the media. Sociology Compass, 1(2), 443-462.

Saeed, A., Blain, N. \& Forbes, D. (1999). New ethnic and national questions in Scotland: post-British identities among Glasgow Pakistani teenagers. Ethnic and Racial Studies 22(5), 821-844.

Scott, A., Pearce, D. \& Goldblatt, P. (2001). The sizes and characteristics of the minority ethnic populations of Great Britain - latest estimates. Population Trends, 105, 6-15. Smith, A.D. (1989). The origins of nations. Ethnic and Racial Studies, 12(3), 340-67. Smith, A.D. (1991) National Identity. London: Penguin.

Solomos, J. (1993). Race and Racism in Britain. Basingstoke: Palgrave Macmillan. Triandafyllidou, A. (2001). Immigrants and National Identity in Europe. London: Routledge. Turner, J. C., Hogg, M. A., Oakes, P. J., Reicher, S. D. \& Wetherell, M. S. (1987). Rediscovering the Social Group: A Self-categorization Theory. Oxford: Blackwell. Vadher, K. \& Barrett, M. (2009). Boundaries of Britishness in British Indian and Pakistani young adults. Journal of Community and Applied Social Psychology, 19, 442-458. Vertovec, S. (2007). Super-diversity and its implications. Ethnic and Racial Studies, 30(6), 1024-54.

Vignoles, V. L., Chryssochoou, X. \& Breakwell, G. M. (2002). Evaluating models of identity motivation: self-esteem is not the whole story. Self and Identity, 1, 201-218.

Wellings, B. (2008). Rump Britain: Englishness and Britishness, 1992-2001. National Identities, 9, 395-412.

Williams, J. (2000). Asians, cricket and ethnic relations in Northern England. Sporting Tradition, 16(2), 39-53. 